\title{
Behavior towards HIV among the Spouse of Male Migrants in Mid- western Nepal- A cross-sectional study
}

\section{Abstract}

Background: Foreign labor migration has over the years, become major features of Nepal's economy and society. In seek of opportunities; many of people of reproductive age group migrate to destination countries where they are exposed to risky behaviors. This study aimed to study HIV related knowledge and vulnerability of these women.

Methods: The cross-sectional study was carried out among 150 spouses of migrant workers in Dhanauri VDC of Dang District. Semi-structured questionnaire was designed to collect the information from the respondents to meet objectives of the study. Data was analyzed by using SPSS(15.0). Ethical permission was obtained by Institutional Ethics Committee.

Results: Almost all respondents had heard of HIV and AIDS and 55\% had poor comprehensive knowledge on HIV prevention; $32 \%$ perceived HIV could transmit through mosquito bite; sharing meal of infection person (59.3\%). The women ever discussed about sex with their husbands were $25.3 \%$, among them 77.1 percent of spouse of male migrants doesn't use condom during sexual intercourse during husband's last visit at home. Major reason was they didn't think it is necessary (88.1 percent) to use.

Conclusion: The study revealed, despite great attention to HIVIAIDS program by Government and other agencies the knowledge on HIV prevention is below 50\%. Comprehensive education program is needed to increase the level of correct knowledge on HIV prevention among wives of migrant workers. Targeted intervention among wives of migrant workers is important to make them able to negotiate for safe sexual practices with their husbands for HIV prevention and disclose their status for accessing services.

Keywords: HIV and AIDS, knowledge, Spousal communication, Vulnerability

\section{Introduction}

In Nepal, after the detection of first case in 1988, HIV situation has evolved from low prevalence of cases to epidemic concentrated among the key affected population i.e. Injectable drug users (IDUs), Female sex workers (FSW) and their clients and men who have sex with men $(\mathrm{MSM})_{1}$. By 2011, total 50,200 estimated people were living with HIV and increasing number of infection was being recorded among low risk general population. Among 15-49 years people, it has prevalence of $0.30 \%_{2}$.

Foreign labor migration has over the years, become major features of Nepal's economy and society. Being a poor economic status, majority of migrants are from the hill and Terai region and destination of one third male migrants is India and other popular countries are middle-east and Malaysia ${ }_{1}$. Due to long term detachment from their family, study suggest that, $9.7 \%$ among the migrants of western and $21.7 \%$ among the migrants of mid-far western region had made the sexual contact with female sex worker. Unfortunately $66.7 \%-80 \%$ migrants didn't use condom during the last sex with FSW and $82.8 \%$ during last sex with their spouse $_{3}$. The prevalence of HIV among wives of migrants as per Integrated Biological and Behavioral Surveillance Survey (2008) was $3.3 \%$. So, it was important to study the HIV related knowledge and vulnerability of these women. Comprehensive knowledge on HIV and AIDS means consistent condom use and having just one uninfected faithful partner can reduce the chances of getting the AIDS virus, knowing that a healthy-looking person can have the AIDS virus, and rejecting the two most common local misconceptions about HIV transmission in Nepal: that HIV can be transmitted by mosquito bites and that HIV can be transmitted by sharing food with a person who has AIDS. 
The present cross-sectional study was carried out in randomly selected Dhanauri VDC located in Dang District. Sampling unit consists of female aged (1549) years whose spouse has spent at least three month in India or other gulf countries and returned home, at least once in the last three years using purposive sampling method. A total of 150 samples were enrolled in the study. Women have aged (1545) years and above, who gave their consent for participation in the study was selected as sample in the study. Ethical approval was obtained from Institution review committee, Manmohan Memorial Institute of Health Sciences prior to study. Data was analyzed by using SPSS ver.15:00.

Descriptive analysis was done for Sociodemographic variable, knowledge on HIV, Condom accessibility and use, interpersonal communication regarding HIVIAIDS and private part problem, knowledge on HIV testing and their uses. Chi-square test was done to report association.

Result

\section{Socio-Demographic Characteristics:}

Out of 150 Sample, Mean age of the spouse of male migrants was 26.1( \pm 7.11$)$ years. Among them, (25-29) year's age group comprised one third i.e. $34.7 \%$ of total no of spouse of male migrant's. Ethnic group which includes, Brahmin,Chhetri were almost $68 \%$ of total population but ethnic group which includes Tharu, Dalit, Magar, Kumal and Bote were $32 \%$ of total population. Finding shows, $88.7 \%$ were literate where as $11.3 \%$ were Illiterate. Almost one third of spouse of male migrants of total population had passed S.L.C and above. As shown in Table 1 shows the 100\% respondent follows the Hindu religion.

\section{Comprehensive Knowledge on HIV:}

Questions on monogamous sexual relationship can prevent from HIV and AIDS, consistent condom use during each sex can prevent from HIVIAIDS, A healthy-looking person can be infected with HIV was asked among 150 respondent, only $65 \%, 71.3 \%, 69.3 \%$ respectively were aware on it. Likewise, 59.3\% of total respondent were aware about the HIV is not transmitted while sharing a meal with an HIV infected person and $32 \%$ of total respondent were aware about a person cannot get the HIV virus from mosquito bite.

Table 2 shows that $17.3 \%$ of total respondent have poor comprehensive knowledge on HIV and AIDS. Similarly, $38.0 \%$ respondent's knowledge was below average and $32.7 \%$ respondent has average comprehensive knowledge on HIV and AIDS. Only $12.0 \%$ respondent has excellent comprehensive knowledge on HIV and AIDS.

\section{Source of Information on HIV and AIDS:}

From table 3, Radio/FM accounts major source of information for spouses of male migrants that was $88.0 \%$. Another major source of information for spouse of male migrants was FCHV which accounts for $47.3 \%$. Next by, Peer/friends was another major source of information which account for $42.7 \%$. IBBS survey 2010 among wives of migrants in four district of far-western Nepal also showed that Radio/FM and FCHVs were the major source of information.

\section{Spousal Communication}

Question that was asked to spouse of male migrants on communication on HIVIAIDS and private part problems to their spouses showed that among one hundred fifty, $25.3 \%$ women had communicate either about HIVIAIDS or Private part problems to their spouses and $74.7 \%$ did not. From table 5, women who had communicate on HIVIAIDS, Most of the spouses of male migrants communicate on preventive measures i.e. 92.1\%. After that, Mode of transmission (MOT) of HIV accounts $63.2 \%$ among total responses.

\section{Condom use with husband during husband last visit to home:}




\section{Original Article}

Most of the respondents $(74.7 \%)$ had sexual contact with their husbands during their last home visit. Only 22.9 percent respondent had used condom during last visit. Among them only 12 percent of respondent used condom all of the time. Almost 72 percent of respondent used condom sometimes only. Major reason of not using condom during sexual intercourse was didn't think it was necessary (88.1\%) which is mentioned below table 4.

\section{HIV testing:}

Table 4 shows, 33.3 percent of total female respondents had known about HIV testing facility, among them only 6 percent of women had done HIV test and only 3 percent of their husband had done HIV test after their last visit and 3 percent women had not known about completion of HIV test of their husband.

\section{Discussion}

On the knowledge related findings found that term HIV and AIDS was universally heard. It could because of the several sources of information. Study shows that radio/TV act as the major source of their information due to their easy access. However, comprehensive knowledge on HIV and AIDS was relatively poor among the female respondent. According to the NDHS report 2010 comprehensive knowledge on HIV and AIDS was 21 percent and 12.5 in IBBS survey 2010 conducted in far-western region but 44.7 percent respondents in this research had comprehensive knowledge about HIV. 65 percent of female respondent were aware about monogamous sexual relationship can prevent from HIV and AIDS. Regarding misconception on MOT by mosquito bite, 32 percent of spouse of male migrants are aware about AIDS virus cannot be transmitted by mosquito bite, which is which is far above (28 percent) than NDHS report 2010 and below (55.68 percent) than HIV awareness, perceived risk level and sexual behavior among spouses of labor migrants and spouses of non-migrants in Gautari VDC of Siraha District ${ }_{5}$.

Regarding misconception on MOT by sharing food, 59.3 Percent of respondent are aware about AIDS virus cannot be transmitted by sharing food which is above (53 percent) than NDHS report 2010 and below (86.36 percent) than research conducted at Gautari VDC .

Almost all (97.3 percent) of respondent had heard about condom and main source of information was Radio (90.4 percent), Husband (56.8 percent) and FCHVs (48.6 percent). Mean time to get condom was 9.49 percent. But similar research conducted at far-western region showed that 97.5 percent respondent had heard about condom which is almost same as this research findings and main source of information was also radio (61.6 percent), $\mathrm{FCHV}$ (59.4 percent), and Husband (18.3 percent).

According to findings of this research, 74.9 percent of respondent had sex with their husband at last home visit, but
77.9 percent of respondent did not use condom during sex. Among respondent who had use condom (22.9 percent), only 12.0 percent of respondent use condom all of the time. But According to the IBBS survey 2010, 97.4 percent respondent had sexual contact among them only 17.2 percent used condom but only 10.5 percent of respondents used condom all the time. So, IBBS survey support this research where result are almost same.

Almost all (97.3 percent) of respondent had heard about condom and main source of information was Radio (90.4 percent), Husband (56.8 percent) and FCHVs (48.6 percent). Mean time to get condom was 9.49 percent. But similar research conducted at far-western region showed that 97.5 percent respondent had heard about condom which is almost same as this research findings and main source of information was also radio (61.6 percent), FCHV (59.4 percent), and Husband (18.3 percent). 


\section{Original Article}

According to findings of this condom (22.9 percent), only 12.0 but only 10.5 percent of
research, 74.9 percent of percent of respondent use respondents used condom all the
respondent had sex with their condom all of the time. But time. So, IBBS survey supports
husband at last home visit, but According to the IBBS survey this research where result is
77.9 percent of respondent did $2010,97.4$ percent respondent almost same.

not use condom during sex. had sexual contact among them Among respondent who had use only 17.2 percent used condom Conclusion

Comprehensive knowledge on HIV and AIDS was relatively poor among the spouse of male migrants and almost more than halve doesn't use condom during sexual intercourse during husband's last visit at home. These finding shows spouses of male migrants are at high risk of HIV and there should extensively conduct the HIV and AIDS awareness program along with screening program.

\section{Acknowledgments}

We are grateful to the Female community health volunteers supporting for making sampling frame and to all the participants sharing their experience with us.

\section{Author contributions}

\section{Disclosure}

The authors declare that they have no competing interest

\section{References}

1. MOHP Nepal NE, ICF international. Nepal Demographic health survey 2011March 2012.

2. NCASC. Nepal Country Progress Report 2012.

3. New era S. Integrated Biological and Behavioral Surveillance Survey among labor Migrants in Districts in western and Mid-Far Western Regions Nepal 2008.

4. Sharma B PA, Shrestha B. Practice of Condom Use Among Spouses of Migrant Workers and Non-migrants in Bardiya District of Nepal. GMC-NEPAL. 2013;6(2).

5. Nayak, s.k., HIV/AIDS Awareness, perceived Risk level and sexual behaviour among spouses of lablor migrants and spouses of non - migrants in Gautri VDC of Siraha district. 2009. 
Table 1: Socio-demographic characteristics of participants

\begin{tabular}{lll}
\hline Variable & Frequency & Percentages (\%) \\
\hline Age group & 18 & \\
15-19 & 39 & 12.0 \\
$20-24$ & 52 & 26.0 \\
$25-29$ & 41 & 34.7 \\
30-39 & & 27.3 \\
Mean Age: 26.14 & & \\
\hline Ethinicity: & 102 & 68.0 \\
Chhetri & 18 & 12.0 \\
Tharu & 16 & 10.7 \\
Dalit & 7 & 4.7 \\
Magar & 7 & 4.7 \\
Kumal and Bote & & \\
& & \\
\hline Education: & 17 & 11.3 \\
Illiterate & 10 & 6.7 \\
Literate & 26 & 17.3 \\
Grade 1-5 & 47 & 31.3 \\
Grade 6-9 & 50 & 33.3 \\
S.L.C and above & & \\
& & \\
\hline Religion: & & 100.0 \\
Hindu & 150 &
\end{tabular}

Table 2: Comprehensive knowledge on HIV

\begin{tabular}{lll}
\hline Knowledge Category & $\begin{array}{l}\text { Frequency } \\
(\mathrm{n}=150)\end{array}$ & $\begin{array}{l}\text { Percentages } \\
(\%)\end{array}$ \\
\hline $\begin{array}{l}\text { Monogamous sexual relationship can prevent from HIV and } \\
\text { AIDS }\end{array}$ & 98 & 65 \\
\hline $\begin{array}{l}\text { Consistent condom use during each sex can prevent from } \\
\text { HIV/AIDS }\end{array}$ & 107 & 71.3 \\
\hline A healthy-looking person can be infected with HIV & 104 & 69.3 \\
\hline A person cannot get the HIV virus from mosquito bite & 48 & 32 \\
\hline $\begin{array}{l}\text { HIV is not transmitted while sharing a meal with an HIV } \\
\text { infected person }\end{array}$ & 89 & 59.3 \\
\hline
\end{tabular}


Original Article

Poor

Below average(median)

Average

Excellent

Total

\section{6}

57

49

18

150
17.3

38.0

32.7

12.0

100.0

Table 3: Source of Information on HIV and AIDS and spousal communication status.

\begin{tabular}{lll}
\hline Source of Information & Number & Percent \\
\hline RadioFM & 132 & $88.0 \%$ \\
TV & 52 & $34.7 \%$ \\
Healthworkers & 36 & $24.0 \%$ \\
NGOs & 14 & $9.3 \%$ \\
FCHV & 71 & $47.3 \%$ \\
PeerFriends & 64 & $42.7 \%$ \\
Husband & 48 & $32.0 \%$ \\
PEOE & 29 & $19.3 \%$ \\
& & \\
\hline Spousal communication & & \\
Status: & 38 & 25.3 \\
Yes & 112 & 74.7 \\
No & 19 & $50.0 \%$ \\
\hline Fatality of HIV & 24 & $63.2 \%$ \\
MOT of HIV & 35 & $92.1 \%$ \\
Preventive measures & 19 & $50.0 \%$ \\
Medical consultation & 13 & $34.2 \%$ \\
Risky sexual behavior & & \\
\hline
\end{tabular}

Table 4: condom use with husband during last visit and HIV testing status

\begin{tabular}{|c|c|c|}
\hline $\begin{array}{l}\text { Sexual contact with husband during his last visit }(n=146) \text { : } \\
\text { No } \\
\text { Yes } \\
\quad \text { Total }\end{array}$ & $\begin{array}{l}\text { Frequency } \\
37 \\
109 \\
\quad 146\end{array}$ & $\begin{array}{l}\text { Percentage } \\
25.3 \\
74.7 \\
\quad 100.0\end{array}$ \\
\hline $\begin{array}{l}\text { Condom use during last sex when husband's last visit }(n=109) \text { : } \\
\text { No } \\
\text { Yes } \\
\quad \text { Total }\end{array}$ & $\begin{array}{l}84 \\
25 \\
109\end{array}$ & $\begin{array}{l}77.1 \\
22.9 \\
100.0\end{array}$ \\
\hline $\begin{array}{l}\text { Frequency of condom use }(n=25) \text { : } \\
\text { All of the time } \\
\text { Most of the Time }\end{array}$ & $\begin{array}{l}3 \\
4\end{array}$ & $\begin{array}{l}12.0 \\
16.0\end{array}$ \\
\hline
\end{tabular}


Original Article

\begin{tabular}{|c|c|c|}
\hline $\begin{array}{c}\text { Sometimes } \\
\text { Total }\end{array}$ & $\begin{array}{l}18 \\
25\end{array}$ & \begin{tabular}{|l|}
72.0 \\
100.0
\end{tabular} \\
\hline $\begin{array}{l}\text { Reason of not using condom(n=84): } \\
\text { Husband objected } \\
\text { Didn't think it was necessary } \\
\text { Didn't think of it } \\
\text { Didn't know/wasn't aware about condoms } \\
\quad \text { Total } \\
\end{array}$ & $\begin{array}{l}3 \\
74 \\
3 \\
4 \\
84\end{array}$ & \begin{tabular}{|l|}
3.6 \\
88.1 \\
3.6 \\
4.8 \\
$\quad 100.0$ \\
\end{tabular} \\
\hline $\begin{array}{l}\text { Known about HIV testing facility }(\mathrm{n}=150) \text { : } \\
\text { No } \\
\text { Yes } \\
\text { Total }\end{array}$ & $\begin{array}{l}\text { Frequency } \\
100 \\
50 \\
150\end{array}$ & $\begin{array}{l}\text { Percentage } \\
66.7 \\
33.3 \\
100.0 \\
\end{array}$ \\
\hline $\begin{array}{l}\text { Known about HIV testing facility }(\mathrm{n}=150) \text { : } \\
\text { No } \\
\text { Yes } \\
\text { Total }\end{array}$ & $\begin{array}{l}\text { Frequency } \\
100 \\
50 \\
150 \\
\end{array}$ & $\begin{array}{l}\text { Percentage } \\
66.7 \\
33.3 \\
100.0 \\
\end{array}$ \\
\hline $\begin{array}{l}\text { HIV test by husband at last home visit }(\mathrm{n}=50) \text { : } \\
\text { No } \\
\text { Yes } \\
\text { Don't know } \\
\text { Total }\end{array}$ & $\begin{array}{l}44 \\
3 \\
3 \\
50\end{array}$ & $\begin{array}{l}88.0 \\
6.0 \\
6.0 \\
100.0\end{array}$ \\
\hline $\begin{array}{l}\text { HIV test by women }(\mathrm{n}=50) \text { : } \\
\text { No } \\
\text { Yes } \\
\text { Total }\end{array}$ & $\begin{array}{l}47 \\
3 \\
50 \\
\end{array}$ & \begin{tabular}{|l}
94.0 \\
6.0 \\
100.0 \\
\end{tabular} \\
\hline
\end{tabular}

